\title{
Modal characteristics of advertising slogans in English and Chinese
}

\author{
Kseniya Skripnik ${ }^{1}$, Anna Gerasimova ${ }^{1}$, Irina Belyaeva ${ }^{1}$, and Ekaterina Kovsh , $^{1,}$ \\ ${ }^{1}$ Moscow Region State University, 10A, Radio Str., 105005, Moscow, Russia
}

\begin{abstract}
The present work explores the modal architectonics of the advertising slogan as a type of microtext in English and Chinese. The authors attempted to describe the basic markers of the text category of modality. According to this data we could carry out the linguistic analysis of the selected language material. The main language models of English and Chinese advertising slogans are revealed, such as: slogan-axiom, slogancommissive, slogan-directive, slogan-interrogative and slogan-qualitative. As the result of the study, we have revealed and distinguished a list of invariant features such as: modal determination, one-system modal construction, monomodality, heterogeneity of language means. They are used to construct a text category of modality in this type of the microtext in the English and Chinese languages, in general, and for each language model, in particular.
\end{abstract}

\section{Introduction}

Currently, we can say that advertising is a complex social phenomenon that has gone far beyond a certain type of human activity. More and more researchers of the modern advertising industry come to the conclusion that advertising is a powerful tool of influence in the social, historical, economic and ideological spheres.

William Arens and Christian Arens characterize advertising as a branch of communication in which art and science coexist at the same time. In their book "Modern Advertising" the authors say that in an advertising message information and knowledge that have been obtained from the science of human behavior effectively interact with the skill and creativity of communicative arts such as literature, dramatic art, theater, graphics, photography. They are used for the purpose of motivating, modifying or strengthening the feelings, beliefs, opinions and behavior of a potential consumer [1].

Chinese scholar Yu Genyuan (于 根 元) notes that an advertising slogan is an important component of an advertising text. Slogan is repeated words in advertising that are specially targeted at the addressee of the message and represent the most important value of a product or service [2].

Chinese researchers say that an advertising slogan has the following characteristics:

- conveys the most important value of goods or services,

- slogan strategy is a long-term benefit,

\footnotetext{
* Corresponding author: angela-1309.m@yandex.ru
} 
- strengthens the image of goods and services, helps to create their own image,

- usually exists in a concise, understandable, expressive and easy to remember form [3$6]$.

The objective of the present study is a detailed description and systematization of the invariant features of the text category of modality. These invariants are used in the construction of micro texts of advertising slogans in English and Chinese.

Of all the components of an advertising message, the advertising slogan has the most interesting research potential for several reasons. First, we can view an advertising slogan as a micro genre of the language of mass communication due to its informative richness and the ability to build up expression [7-11]. Secondly, the slogan has specific text and linguistic construction features. Therefore, we can assume that an advertising slogan refers to a microtext with a special internal and external organization, which can be studied in detail on the basis of the English and Chinese languages. We can add that the relevance of the chosen topic is associated with the need for text linguistics to continue the study of text-forming categories. Also we can understand how text-forming categories take part in the formation of the text as a key communicative component and how to interpret the modal architectonics of the advertising slogan as a microgenre of the language of mass communication. The novelty and scientific significance of this analysis is supported by the fact that there is no special study on the functioning of the text-forming category of modality in the Chinese and English advertising slogans in either domestic or foreign linguistic science.

\section{Materials and Methods}

The material for the study was 500 advertising slogans in English and Chinese, obtained by a continuous sample from the Internet and from modern Chinese magazines "Chinese National Geography". [12-15] In our study we use a complex research methodology, which includes: structural and semantic analysis of linguistic material, the method of typological research of texts and their individual components, as well as the method of context analysis.

S. Balli interprets modality as a syntactic category in the creation of which modal verbs play the dominant role denoting the opinion of the recipient about the subject of the statement. In his paper, S. Balli writes that modality is the soul of an utterance. Therefore, he attributes various shades of judgment, feeling or will to modal meanings which can be expressed using modal verbs, moods, intonations, question forms, orders as well as modal gestures, facial expressions, interjections and other techniques due to which one can attract the attention of the companion [16].

He Yang (贺阳 Hè Yáng) first became interested in in-depth study of the text category of modality in Chinese. He has introduced the Chinese term for the category of modality 语 气 (yŭqi), instead of the previously used English word 'modality'. Another modern sinologist Tang Tinchi (汤廷 池 Tāng Tíngchí) has distinguished three ways of expressing modality in Chinese: modal particles (情 态语气 词 qíngtài yŭqìcí), modal adverbs (情态 副词 qíngtài fùcí) and modal verbs ( 情 态 形容词 qíngtài xíngróngcí) [5].

In his study "Kitaiskii yazik i kitaiskaya pis'mennost'" Russian sinologist M.V. Sofronov writes that the most complete demonstrative ways of modality in Chinese are narration, question and motivation. The author emphasizes that the verbal forms of the indicative and imperative moods express narration and incentive meaning in many Indo-European languages. But it is unacceptable in Chinese, where a question or imperative sentence we can express using official words that are placed at the end of a sentence and refer to the entire statement as a whole. Thus, we can claim that the text category of modality in Chinese is not morphological, but syntactic [17]. 
The author also says that modality in Chinese can be expressed by intonation, namely imperative, interrogative, narrative. In this case, the most important markers of the communicative modality of an utterance are modal particles. Here it can be distinguished three main ones: the modal particle of the narrative 啊 a, 吧 ba, 吗 ma.

The modern Chinese linguist Cui Xilian (崔希亮 Cūī Xīliàng) has developed an interesting system of the text category of modality in Chinese. He identifies three main types of modality:

1. direct modality (直 陈 情态 zhíchén qíngtài), which is associated with the speaker's subjective attitude to the utterance and is expressed using intonation;

2. event modality (事件 情 态 shìjiàn qíngtài) reveals the essence of the situation and is expressed using modal adverbs, verbs proper and additional verb elements (verb modifiers);

3. modality of possibility, desire, obligation (能源 情 态 néng yuàn qíngtài), which is expressed through modal verbs [5].

S.A. Simatova gives the analysis of the most used modal particles in Chinese. In her research, the author identifies:

a) in oral

啊 $\mathrm{a}$ - an expression of various feelings and emotions in exclamation sentences,

呢 ne-a special or alternative question;

了 le-a marker of a change in a situation or state ,

吧 $\mathrm{ba}$ - an expression of uncertainty in general questions and conditional sentences, a expression of consent and motivation ,

吗 ma - designates a general question;

b) in writing:

啊 a, 了 le, 呢 ne, 的 de - strengthening of the statement, often implemented in the excretory structure [3].

Based on the above, we can represent the modal structure of the text as a set of linguistic means of morphological, syntactic and lexical levels that provide orientation of the listener or reader in the modal functional world of the created text [18].

According to the in-depth analysis and colligation of the available information we can distinguish the following invariant features, so it is possible to identify the text category of modality in the microtext of advertising slogan [19]:

1. Modal determination of the described events in the text - options for the correlation of objective events with linguistic expressions in the text (morphological, lexical, lexicosemantic).

2. The consistency of the modal organisation of the text - the presence of modal subsystems of the author and characters.

3. Modal text type - polymodal or monomodal texts.

4. The main form of modal text formation.

5. Homogeneous or heterogeneous type of text - using various methods of expressing modality.

Thus, the text category of modality is characteristic of any utterance to one degree or another; therefore, we can say that an advertising slogan in English and Chinese as a type of microtext should show signs of modality. An advertising slogan does not belong to the class of texts where a dichotomy is possible - the speech of the author and the characters, but emotionally, a monologue statement always has a pronounced character. For example, 'Not trying it would be a Greek tragedy! CARTE D'OR ice-cream'.

Based on the foregoing, we can say that in Indo-European and Oriental languages, the modal meaning of an utterance is conveyed using the following linguistic means:

1. Moods (in English): indicative, subjunctive and imperative or with the help of an independent infinitive. 
2. Modal words, adverbs, modal particles.

3. Modal verbs.

4. Sentence intonation.

\section{Results}

Now we can move on to a detailed study of advertising slogans in English from the position of forming modal architectonics in this type of micro text.

Consider the English slogan-axiom: 'Allstate. You're in good hands'.

The modal architectonics of this advertising slogan in English is built with the indicative mood of the present tense verb. The popularity of this structure of the compositional construction of the advertising message we can explain as the indicative sentence is the main tool in the language with which one can describe an event or reality. Thus, the product or service referred to in the advertising slogan initially has the connotation of "reality, truthfulness", thereby attracting the attention of the consumer, as an unquestionable fact. The modal architectonics of the studied English advertising slogan can be characterized as modal determined, one-system (as only the author's monologue speech is present, and the characters are only implied), monomodal (as microtext describes the modality of reality, which is expressed by the form of the indicative mood), heterogeneous (as except for the verb form of the indicative mood there is vocabulary with a positive tone of the message: 'in good hand' - stability and confidence). Here we can talk about the determined modality of real time.

Study an interesting advertising slogan-axiom: 'If it tasted any fresher it would still be on the tree. Tropicana Orange Juice'.

We can say that in this example the subjunctive mood carries the connotation of "unreality", "imaginary possibility" of the described events. In this case, the author deliberately uses a less common technique to create a modal tone of this advertising message. It is the right decision. Thus, he emphasizes that the freshness and naturalness of the advertised orange juice we can only compete with the fresh fruit on the tree. The modal architectonics of this advertising slogan in English, based on the selected invariant features, can be interpreted as modal determined, one-system (the author's speech is present), monomodal (subjunctive mood), heterogeneous (as in addition to the form of the verb in the subjunctive mood, the conjunction 'If' and the modal verb 'would be', comparative evaluative adjectives 'fresher' are used). Consequently, the determined modality of unreality dominates here due to the subjunctive mood.

Let us turn to the study of another group of English messages, which includes sloganaxiom (1-2) and slogan-directive (3):

1. Burger King. Sometimes you have to break the rules.

2. Yamaha. The way it should be.

3. US Army. Be all that you can be.

The modal framework of the examples give precisely distinguished modal markers such as modal verbs - 'have to', 'should', 'can', which help the addressee of the advertising message to model the microclimate of "duties, the possibility, and the inevitability of the described events". The modal picture of these micro texts can be described as one-system (only the author's statement), monomodal and heterogeneous (as in addition to modal verbs, adverb of the time 'sometimes' and imperative mood are also used). We can emphasize that the degree of saturation with modal indicators in these advertising slogans is also quite high. We can talk about the determined modality of obligation, functioning with the help of modal verbs, indicative or imperative forms.

The analysis of the slogan-commissive will be interesting in this context: DHL. We keep your promise. 
The modal structure of this utterance in English is also built around the verb in the present tense, indicative mood. The type of micro text can be defined as modal determined, onesystem (only the author's monologue speech is present), monomodal (as microtext carry the modality of reality), heterogeneous (as in addition to the indicative mood form, there is vocabulary that carries a positive tone of the message: 'promise' - "reliability").

Explore one more English slogan-axiom: Oh Fab, I'm glad they put real botax in you. Fab deterrents

Although interjections are considered as a relatively unproductive part of speech, they play a key role in creating the modal framework in this microtext. The modal architectonics of the presented example is defined as determined (the main indicator of the emotional attitude of the speaker or writer is the exclamation interjection 'Oh'), one-system (only the author's speech), monomodal (it expresses the unambiguous modal meaning of the entire statement - admiration, joy from the use of the advertised object), heterogeneous (the verb form in the indicative mood and vocabulary with the meaning of "joy" - 'I'm glad were used'). The degree of emotional saturation in this slogan is also quite high. We can talk about the determined modality of admiration based on modal interjections, a verb in the form of an indicative and a vocabulary with positive connotation.

Finally, for comparison, consider the model of a slogan-interrogative: Verion Wireless. Can you hear me now?

Modal marker of this rhetorical question is the modal verb - 'can', which helps to create an atmosphere of obligation, opportunity, inevitability of the described events. The modal picture of this microtext can be described as determined, one-system (only the author's statement), monomodal and heterogeneous (as in addition to modal verbs, an interrogative construction are also used). The modal architectonics of this statement has a well-expressed tonality of the rhetorical question, built at the expense of a modal verb.

The next logical step to create a complete picture of building a modal frame of an advertising slogan will be a detailed examination of the language material in Chinese.

Firstly, we will consider slogans-axiom (1-2) and a slogan-commissive (3) with modal verbs:

1. LIN NIN. 一切皆有可能! Yīqiè jiē yǒu kěnéng! Everything is possible!

2. 有路必有丰田车! Yǒu lù bì yǒu fēngtián chē! - 丰田 Where there is a road - there must be TOYOTA!

3. CANON EOS. 招呼想象的视角会今你惊! Zhāohū xiăngxiàng de shìjiăo huì jīn nǐ jīngtàn! You will be pleasantly surprised if you trust your imagination!

Analyzing these examples, we can state that with the help of modal verbs such as: 可能 - possible; 会 - possible; 必 - certainly, undoubtedly, it should be - the authors of advertising messages represent their personal attitude to the advertised goods. They focus the consumer's attention on the concept of exclusivity and perfection of these goods. The type of micro text can be defined as determined, one-system (author's speech), monomodal, heterogeneous (we can see modal verbs and exclamation structures). It expresses the determined tonality of possibility, built on modal verbs.

Consider another emotional slogan-axiom: 即使你把它拆得七零八落, 它依然是 位 美人! Jíshǐ nǐ bă tā chāi dé qī líng bā luò, tā yīrán shì wèi měirén! Even if you take it apart into details, it will still be beautiful! - 宝马 BMW

The linguistic architectonics of the studied slogan can be identified as determined, the key marker of the modal subjunctive meaning is the conjunction: 即使 ...... 依然 - even if..., it doesn't matter. It is used to create an atmosphere of unreality of the described phenomena, which at the same time helps the author to emphasize the uniqueness and inimitable beauty of the advertised car brand. The type of microtext is defined as one-system (only the author's monologue speech), monomodal, heterogeneous (as to create an atmosphere of uniqueness 
and exclusivity along with the conjunction, the author uses the verbal construction 拆得七 零八落, phraseological locution 七零八落 - “to crumble in disorder; scattered”, a modal words with the meaning “inevitability, high probability” - 依然 “all the same ”, a qualitative adjective 美 - “ beautiful ”, as well as exclamation intonation). This slogan has a high degree of modal determination of probability due to the conjunction of the subjunctive mood.

There is another peculiar Chinese slogan-commissive: 你买汽车不考虑克莱斯勒, 你就吃亏了, 不但你吃亏, 我们也吃亏。Nǐ măi qìchē bù kăolǜ kèláisīlēi, nǐ jiù chīkuīle, bùdàn nǐ chīkuī, wǒmen yě chīkuī. If you are not thinking about Chrysler, then you are wrong. Not only you will lose, but so we will. - Chrysler

The modal architectonics of this advertising slogan we can identify as determined, as the main marker of modal meaning are the conjunction:（要是） ....., 就 - if..., then..., 不但 ....... 也 - not only... but also.... These conjunctions are used to describe the possible consequences of an event, thus helping the author to highlight the undeniable value of the advertised car brand. The type of text is defined as one-system, only the author's monologue; monomodal and heterogeneous (to create a modal atmosphere of the utterance, along with the conjunction, the author uses the polysemic verb 吃亏, which, has the following meanings: 1) incur a loss; to fail; 2) cause harm; 3) disgrace, goofy, miscalculate; 吃眼前 in front of everyone, publicly disgrace 4) be hurt by (smb.) suffer an insult; 我吃了他的 亏 I suffered from him; he offended me 5) unfortunately) [20]. Thus, this advertising slogan in Chinese has a high modal probability based on conjunctive constructions and synsemantic verb.

Let's see how things are in the Chinese advertising slogans-directive:

1. 雷诺 Renault 让汽车成为一个小家! Ràng qìchē chéngwéi yīgè xiăo jiā! Let the car become a small home!

2. 可口可乐 - 喝 可口可乐吧! Kěkǒukělè - hē kěkǒukělè ba! Drink Coca-Cola!

The signals of the imperative modality in these advertising slogans in Chinese are the causative verb 让, which means "permission, permission to perform this or that action," and the modal particle 吧, which is placed at the end of the utterance and expresses a request, belief, call or order to performing an action. The advertiser deliberately uses the presented language techniques in order to activate the addressee's attention to the described subject or event, and thereby push the consumer to purchase the advertised product. We can say that in this case the modal framework is characterized as determined, one-system, monomodal (imperative modality) and homogeneous. Thus, we can come to the conclusion about a strong incentive modality of the studied linguistic material, expressed by the imperative mood.

And what about the slogans-qualitative in Chinese? Consider some slogans:

1. 简单, 聪明, 能干! Jiăndān, cōngmíng, nénggàn! Simple, smart, sensible!

2. 一位 清 管, 一方 繁华, 一个贪官, 一方 遭殊! Yī wèi qīng guăn, yīfāng fánhuá, yīgè tānguān, yīfāng zāoyāng! An honest official is a prosperous country; a corrupt official is a poverty-stricken country.

The modal architectonics of these advertising slogans we can define as determined, the main modal markers are exclamation tonality, vocabulary with a positive connotation: 简单, 聪明, 能干 - simple, smart, sensible; 繁华 - prosperous; and vocabulary with a negative tone: 贪官 - a corrupt official, 遭殊 - a suffering country. The type of microtext is characterized as one-system (author's speech), monomodal (exclamation tone of the reality of the described events), heterogeneous. Here we can talk about the determined tone of the exclamation. 


\section{Discussion}

At this stage of our study, it is necessary to summarize the intermediate results on the problem of constructing the text category of modality based on advertising slogans in two different languages: English and Chinese.

The results of our analysis let us draw some particular interesting conclusions:

Firstly, the key signals of modality in English and Chinese advertising slogans are grammatical and lexical units of modal expression, such as:

1. Verb forms of mood in Chinese and English, expressing the modalities of reality or unreality of the described events:

a) the indicative mood, which makes up $28 \%$ of the entire study material and is the most common linguistic phenomenon in these languages;

b) the imperative mood, which makes up $15.3 \%$ of all the considered linguistic material and is the second most popular linguistic technique;

c) the subjunctive mood, which is a rare linguistic phenomenon for the construction of modal mood in the microtexts of advertising slogans in two languages (which is only $1 \%$ of the total linguistic material).

2. Vocabulary with positive meaning.

3. Modal verbs that are found in advertising slogans and make up about $5 \%$ of the total lexical material.

4. Modal words are identified only in English, which is $2 \%$ of the studied material. It is not found in Chinese due to the peculiarities of the lexical structure.

5. Modal particles are found in several Chinese slogans, which is $0.6 \%$ of the original lexical corpus.

6. Exclamation intonation is found in advertising slogans in all languages, which is $31.6 \%$ of the total analyzed language material.

The identified language means with the modal meaning we can classify according to the following indicators:

1. Single: modal particles (Chinese).

2. Universal: narrative, imperative, vocabulary with a positive connotation, modal verbs.

3. General: exclamation intonation, modal words, subjunctive mood.

Secondly, based on the revealed characteristics of the text category of modality in English and Chinese advertising slogans, we can conclude that:

- slogan-commissive has the modality of possibility or probability due to the conjunction and modal verbs;

- slogan-directive expresses an incentive modality based on the imperative and verbs of obligation;

- slogan-interrogative shows the interrogative modality with the help of interrogative particles;

- slogan-axiom has the modality of subjective reliability, based on the forms of the indicative or subjunctive moods, modal verbs;

- slogan-qualitative tends to an exclamation or an affirmative modality.

Finally, the modal architectonics of micro texts of advertising slogans in English and Chinese is characterized as determined, monomodal, one-system (there is a monologue in $100 \%$ of cases) and heterogeneous in terms of the presence of linguistic means that are used to create modal concept of uniqueness and attractiveness of advertised product or service. At the same time, we should emphasize the high modal intensity of advertising slogans as types of microtext. The selected invariant features of the text category of modality were systematized according to three characteristics, so we have drawn up the following scheme (see Figure 1): 


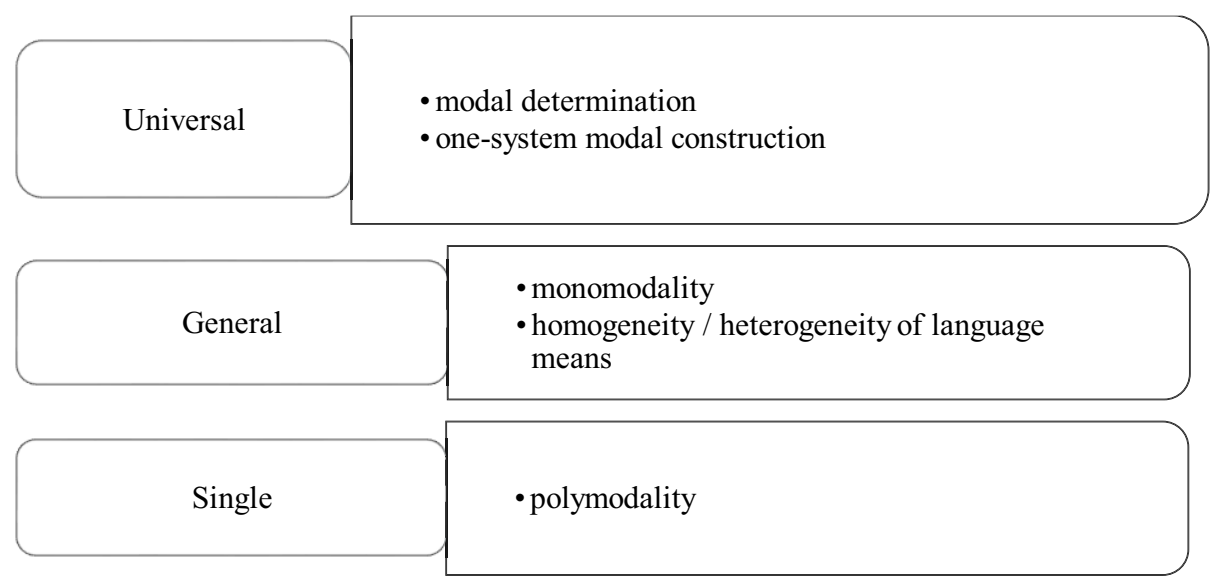

Fig. 1. Classification of invariant modality features.

We would like to note that the presence of a desirable, motivating modality or modality of reality in advertising slogans suggests that they have a mandatory modal determination, which is undoubtedly due to the main function of this type of micro text - to attract the attention of the addressee. In conclusion, we should emphasize that the main pressure of the modal architectonics in English and Chinese advertising slogans as a special kind of microtext is expressed with the grammatical means of the language, supported by semantic markers: nouns, adjectives, verbs, adverbs with modal meaning. These modal indicators need to form modal shades of exclusivity, necessity, attractiveness, thus creating a positive, desired attitude of the consumer towards the advertised goods.

\section{Conclusion}

Summing up, we can say that the slogan as a small genre of advertising communication has characteristics that make it possible to identify it as a specific type of grammatical micro text.

The results of the study demonstrate the effectiveness of interpreting the linguistic architectonics of an advertising slogan as a type of microtext based on text-forming category such as modality and its invariant features. We should submit that further study of advertising slogans in other languages will make it possible to identify another list of variant features of the micro text linguistic architectonics within advertising communication. From there it will undoubtedly have a beneficial effect on expanding and updating the theory of grammatical construction of the text, and will help to supplement the general typology of texts within the framework of language theory.

\section{References}

1. W. Arens, Ch. Arens, M. Weigold, Advertising (McGraw-Hill, 2014)

2. Yu Genyuan, Introduction to Language (Beijing, China Radio and Television Press, 2007)

3. Peng Lizhen, Modern Chinese Modality Research (Beijing, China Social Sciences Press, 2007)

4. Zhao Hong, Advertising Language Art (Beijing, China Economic Publishing House, 2004) 
5. Huang Xiaoping, Advertising Language (Kunming, Yunnan People's Publishing House, 2012)

6. Ju Huibing, Advertising Culture (Beijing, Beijing Normal University Press, 2013)

7. K.V. Shido, Reklamnyy slogan kak osobyy zhanr angliyskikh reklamnykh tekstov: avtoref. dis. ... kand. filol. Nauk (Saratov, 2002)

8. A. Goddard, The Language of Advertising Written Texts (UK, Taylor\& Francis LTD, 2002)

9. J.B. Haskins, Successful advertising research methods (NTC Publishing group, Illinois, USA, 1993)

10. J. Hood, Selling the Dream: Why Advertising Is Good Business (Praeger Publishers, 2005)

11. F. Jefkins, Advertising made simple (Heinemann, 1982)

12. 77 catchy and creative slogans//Hongkiat, http://www.hongkiat.com/blog/77-catchyand-creative-slogans/

13. 40 best advertising slogans modern brands//Advertise, http://www.advergize.com/advertising/40-best-advertising-slogans-modern-brands/

14. Adslogans, http: // www. adslogans. co.uk. /

15. Chinese National Giography, http://www.dili360.com

16. S. Balli, Obshchaya lingvistika i voprosy frantsuzskogo yazyka (M., 1955)

17. M.V. Sofronov, Kitayskiy yazyk i kitayskaya pis'mennost' (M., Vostok-Zapad, 2007)

18. S.A. Simatova, Vestnik Sankt-Peterburgskogo universiteta 13.4 (2014)

19. M.N. Levchenko, Interpretatsiya teksta $i$ yego grammaticheskikh modeley (tipologicheskiy aspekt): monografiya (M., MGOU, 2013)

20. A Chinese-Russian Dictionary (Beijing, China Economic Publishing House, 2004) 